\title{
Acidophilic Cell
}

National Cancer Institute

\section{Source}

National Cancer Institute. Acidophilic Cell. NCI Thesaurus. Code C32044.

A cell whose cytoplasm or its granules stain with acid dyes. 